\title{
THE TECHNICAL AND PHYSICAL PREPARATION OF BASKETBALL PLAYERS
}

original paper

( ) University School of Physical Education in Wroclaw

DOI: https://doi.org/10.5114/hm.2018.77321

\section{VICTOR KORYAHIN $^{1}$, MYROSLAV DUTCHAK ${ }^{2}$, GENNADII IEDYNAK ${ }^{3}$, OKSANA BLAVT ${ }^{1}$, LESIA GALAMANDJUK ${ }^{3}$, ELENA CHEREPOVSKA ${ }^{1}$}

${ }^{1}$ Department of Physical Education, National University, Lviv Polytechnic, Lviv, Ukraine

${ }^{2}$ Department of Health, Fitness and Recreation, National University of Ukraine on Physical Education and Sport, Kyiv, Ukraine

${ }^{3}$ Department of Theory, Methodology of Preschool and Elementary School Education, Kamianets-Podilskyi National Ivan Ohiienko University, Kamianets-Podilskyi, Ukraine

\begin{abstract}
Purpose. The study aim was to analyse the technical and physical preparation of highly qualified basketball players, as well as to determine the level of development of their aerobic and anaerobic functions.

Methods. When conducting laboratory examinations on a cycloergometer, for the purpose of determining the level of aerobic and anaerobic potential of basketball players, measurements of pulmonary ventilation, the level of oxygen consumption and the allocation of carbon dioxide, and the frequency of cardiac contractions were carried out.

Results. The paper presents results concerning the technical and physical preparation level of highly qualified basketball players, as well as the level of development of their aerobic and anaerobic functions, taking into account play functions.

Conclusions. The results revealed a need to increase the efficiency of high-level players training system. It was also observed that, despite positive changes, the training system applied in basketball did not ensure sufficient impact upon the energy functions of highly qualified basketball players.
\end{abstract}

Key words: physical, technical, functional training, highly qualified basketball players

\section{Introduction}

The choice of an effective system of training highly qualified basketball players is very complex, if it is not known, on the one hand, which requirements are put forward to the athletes by the play itself, and, on the other hand, what level of their technical, physical, and other types of preparation is and how it is implemented during the play [1-3]. The most acute issue is the definition of requirements for technical, and especially physical and functional fitness of sportsmen in sports games [4-8]. The absence of a clear relationship between the indicators of technique, motor activity, and functional changes in the body of athletes of these kinds of sports does not allow to fully proceed from the results of sports performances.
The purpose of the paper was to study the technical and physical preparation of highly qualified basketball players, as well as to determine the level of development of their aerobic and anaerobic functions.

\section{Material and methods}

\section{Participants}

The total of 69 sportsmen took part in the experiment, designed to determine the level of technical and physical preparation of basketball players. All of them were honoured masters of sports and masters of sports of the international class. Each athlete was informed about the research design and the requirements, benefits, and risks of the study.

Correspondence address: Oksana Blavt, Department of Physical Education, National University, Lviv Polytechnic,

Str. Bandera, 12, Lviv, 79013, Ukraine, e-mail: oksanablavt@ukr.net

Received: April 29, 2018

Accepted for publication: May 23, 2018

Citation: Koryahin V, Dutchak M, Iedynak G, Blavt O, Galamandjuk L, Cherepovska E. The technical and physical preparation of basketball players. Hum Mov. 2018;19(4):29-34; doi: https://doi.org/10.5114/hm.2018.77321. 
Overall, 74 honoured masters of sports and masters of sports of international class took part in the experiment for the purpose of determining the level of aerobic and anaerobic potential of basketball players, which satisfied the requirements concerning the sample volume at the confidence level of $p<0.05$.

\section{Methods}

To obtain the necessary data, an examination program was implemented including 9 special tests. These tests met the established requirements [3, 9-12].

When conducting laboratory examinations on a cycloergometer, for the purpose of determining the level of aerobic and anaerobic potential of basketball players, measurements of pulmonary ventilation, the level of oxygen consumption and the allocation of carbon dioxide, and the frequency of cardiac contractions were carried out.

\section{Statistical analysis}

All statistical analyses were performed with the SPSS software, version 21, adapted to medical and biological research. All variables were tested for their conformity with the assumption of distributional normality; Student's $t$-test was applied. The significance for all statistical tests was set at $p<0.05$.

\section{Ethical approval}

The research related to human use has been complied with all the relevant national regulations and institutional policies, and has followed the tenets of the World Medical Association (WMA) Declaration of Helsinki - ethical principles for medical research involving human subjects.

\section{Informed consent}

Informed consent has been obtained from all individuals included in this study.

\section{Results}

The results referring to the physical preparation of the highly qualified basketball players are presented in Table 1. As it is seen, the running time of the 6-m running in the basketball players performing central functions is $1.30 \pm 0.041 \mathrm{~s}$, which is lower than in the forwards $(1.26 \pm 0.035 \mathrm{~s})$ and defenders $(1.23 \pm$ $0.031 \mathrm{~s})$. But it should be borne in mind that the difference is only between the indicators of the centre players and defenders $(p<0.01)$. This means that the starting speed of the defenders is better than that of the central players.

If one analyses the data of the 20-m running at 20 $\mathrm{m}$, it turns out that the forwards and the centre players are inferior to the defenders, with a high level of reliability difference between the indicators. The maximum speed at the distance in the centre players is lower than that of the forwards and defenders. The increase in speed in the run from 6 to $20 \mathrm{~m}$ is $1.50 \pm 0.104 \mathrm{~m} / \mathrm{s}$ in the centre players and $1.70 \pm 0.124 \mathrm{~m} / \mathrm{s}$ in defenders $(p<0.01)$. Thus, it is observed that tall basketball players, especially those who perform the functions of central players, are inferior to the defenders in the initial acceleration, in the possibility of developing maximum speed at the distance, and in the results of 20-m running.

However, it should be noted that in quite a number of indicators that characterize speed qualities of basketball players (35\% of the total number), the difference is absent or insignificant. This suggests significant positive changes in the training system of speed qualities in highly qualified basketball players. The high jumping analysis revealed a low level of development of this quality in the highly qualified basketball players. The results of the jump height in the basketball players of different play functions, as evidenced by the study results, are different. The defenders' jump height is $57.7 \pm 2.71 \mathrm{~cm}$, which, on average, is by $8.2 \mathrm{~cm}$ more than among the centre players $(p<0.01)$ and by $5.3 \mathrm{~cm}$ more than in the forwards $(p<0.05)$.

The correlation analysis carried out between the height data and the jump height indicators in highly qualified basketball players showed that there was a rather high but negative dependence $(r=-0.589)$ between them.

The study has proved that in terms of the development of general and special high-speed endurance in basketball players of high qualification, there are significant reserves, especially in the centre players. The average factor in the Cooper test is $2845.3 \pm 91.4 \mathrm{~m}$ in the centre players, $3075.5 \pm 53.5 \mathrm{~m}$ in forwards, and $3087.9 \pm 71.5 \mathrm{~m}$ in defenders. The difference between the average indicators of the centre players and defenders is significant and equals $242.6 \mathrm{~m}$, whereas between the centre players and the forwards it is $230.2 \mathrm{~m}$. It should be noted that the height of the forwards, as well as of the central players is above $200 \mathrm{~cm}$.

The indicators of special high-speed endurance show similar results. During the test, the average indicator in the $3 \times 40$-s running is $560.9 \pm 10.04 \mathrm{~m}$ in the centre players, $581.2 \pm 6.52 \mathrm{~m}$ in the forwards, and $548.8 \pm 10.92 \mathrm{~m}$ in the defenders. The difference be- 
Table 1 . Results of the tests on physical preparation in highly qualified basketball players

\begin{tabular}{|c|c|c|c|c|}
\hline \multirow{2}{*}{ Indicators } & \multicolumn{3}{|c|}{ Players' functions } & \multirow{2}{*}{$\begin{array}{l}\text { Difference } \\
\text { certainty }\end{array}$} \\
\hline & Centre players $(\mathrm{C})$ & Forwards $(\mathrm{F})$ & Defenders (D) & \\
\hline 20-m running & $(n=15)$ & $(n=17)$ & $(n=20)$ & $(\mathrm{C}-\mathrm{F}) p<0.01$ \\
\hline - 6-m running time (s) & $1.30 \pm 0.041$ & $1.26 \pm 0.035$ & $1.23 \pm 0.031$ & $\begin{array}{l}(\mathrm{C}-\mathrm{D}) p<0.01 \\
(\mathrm{~F}-\mathrm{D}) p<0.05\end{array}$ \\
\hline - 20-m running time (s) & $3.30 \pm 0.082$ & $3.13 \pm 0.049$ & $3.04 \pm 0.027$ & $\begin{array}{l}(\mathrm{C}-\mathrm{F}) p<0.01 \\
(\mathrm{C}-\mathrm{D}) p<0.001 \\
(\mathrm{~F}-\mathrm{D}) p<0.01\end{array}$ \\
\hline - maximum speed at a distance $(\mathrm{m} / \mathrm{s})$ & $6.08 \pm 0.016$ & $6.38 \pm 0.021$ & $6.60 \pm 0.031$ & $\begin{array}{l}(\mathrm{C}-\mathrm{F}) p<0.01 \\
(\mathrm{C}-\mathrm{D}) p<0.001 \\
(\mathrm{~F}-\mathrm{D}) p<0.01\end{array}$ \\
\hline - increase in speed from 6 to $20 \mathrm{~m} \mathrm{(m/s)}$ & $1.50 \pm 0.104$ & $1.61 \pm 0.100$ & $1.70 \pm 0.124$ & $\begin{array}{l}(\mathrm{C}-\mathrm{F}) p<0.05 \\
(\mathrm{C}-\mathrm{D}) p<0.01 \\
(\mathrm{~F}-\mathrm{D}) p<0.05\end{array}$ \\
\hline Jump height & $(n=27)$ & $(n=15)$ & $(n=27)$ & \\
\hline $\begin{array}{l}\text { - height standing on tiptoes with the hand } \\
\text { above the head }(\mathrm{cm})\end{array}$ & $279.6 \pm 2.4$ & $271.0 \pm 3.49$ & $256.9 \pm 3.42$ & $\begin{array}{r}(\mathrm{C}-\mathrm{F}) p<0.05 \\
(\mathrm{C}-\mathrm{D}) p<0.01 \\
(\mathrm{~F}-\mathrm{D}) p<0.01\end{array}$ \\
\hline - absolute jump height (cm) & $328.1 \pm 3.12$ & $324.1 \pm 3.65$ & $314.4 \pm 3.42$ & $\begin{array}{r}(\mathrm{C}-\mathrm{F}) p<0.05 \\
(\mathrm{C}-\mathrm{D}) p<0.01 \\
(\mathrm{~F}-\mathrm{D}) p<0.01\end{array}$ \\
\hline Cooper test & $(n=17)$ & $(n=20)$ & $(n=21)$ & $(\mathrm{C}-\mathrm{F}) p<0.01$ \\
\hline - number of meters for $12 \mathrm{~min}$ of running & $2845.3 \pm 91.4$ & $3075.5 \pm 53.5$ & $3087.9 \pm 71.5$ & $\begin{array}{l}(\mathrm{C}-\mathrm{D}) p<0.01 \\
(\mathrm{~F}-\mathrm{D}) p<0.05\end{array}$ \\
\hline $3 \times 40$-s running after 1 min rest & $(n=12)$ & $(n=15)$ & $(n=21)$ & $(\mathrm{C}-\mathrm{F}) p<0.05$ \\
\hline - number of meters for $120 \mathrm{~s}$ of running & $560.9 \pm 10.04$ & $581.2 \pm 6.52$ & $548.8 \pm 10.92$ & $\begin{array}{l}(\mathrm{C}-\mathrm{D}) p<0.05 \\
(\mathrm{~F}-\mathrm{D}) p<0.01\end{array}$ \\
\hline
\end{tabular}

tween the indicators of the centre players and the forwards is $20.3(p<0.05)$; it is $12.7 \mathrm{~m}(p<0.05)$ between the centre players and defenders, and $32.4 \mathrm{~m}(p<0.01)$ between the forwards and defenders.

The analysis of the study results of the highly qualified basketball players' technical preparation (Table 2) has shown that the advantage of the defenders over the centre players and forwards is observed in all indicators, with the exception of two: the work time in the ball shooting in a jump from $40 \mathrm{~m}$ test and overall work ability in shots.

This suggests that the level of technical preparation of tall players has significant reserves, especially in passing the basketball using one hand from the shoulder performed with the use of the 'weaker' hand (usually the left hand), and in the foul shot. It is known that during the match, tall players, especially centre players, most often perform foul shots. But they have a lower scoring rate of $24.0 \pm 1.43(83.8 \%)$, while a scoring rate of defenders is $26.5 \pm 0.689$ (88.3\%). The reliability of the difference between the indicators is high $(p<0.01)$.

The analysis of the functional capabilities of basketball players showed that the maximum oxygen consumption in basketball players of high qualification reached the value of $58.5 \pm 5.59 \mathrm{ml} / \mathrm{kg} / \mathrm{min}$.

The average indicators of critical power in highly qualified basketball players equalled $1741 \mathrm{~kg} / \mathrm{min}$, anaerobic exchange threshold: $60.7 \%$, physical working capacity: $170-1325 \mathrm{~kg} / \mathrm{min}$; the total 'excess' of $\mathrm{CO}_{2}$ emission was 4.861 .

The analysis of the functional capability indicators of highly qualified basketball players, with the consideration of their game functions, showed that the reliable difference between them was observed in $25.9 \%$ of cases. The difference between the indicators of the central players and forwards was significant in $16.6 \%$ of cases, between centre players and defenders in $55.5 \%$ of cases, and between forwards and defenders in $5.5 \%$ of cases. 


\section{HUMAN MOVEMENT}

V. Koryahin et al., The technical and physical preparation of basketball players

Table 2. Results of the tests on technical preparation in highly qualified basketball players

\begin{tabular}{|c|c|c|c|c|}
\hline \multirow{2}{*}{ Indicators } & \multicolumn{3}{|c|}{ Players' functions } & \multirow{2}{*}{$\begin{array}{l}\text { Difference } \\
\text { certainty }\end{array}$} \\
\hline & Centre players $(\mathrm{C})$ & Forwards (F) & $\overline{\text { Defenders (D) }}$ & \\
\hline Movement in the defender's position & $(n=18)$ & $(n=19)$ & $(n=17)$ & \\
\hline - time per $100 \mathrm{~m}(\mathrm{~s})$ & $35.31 \pm 2.26$ & $34.01 \pm 1.21$ & $32.27 \pm 1.09$ & $(\mathrm{C}-\mathrm{F}) p<0.05$ \\
\hline Passing the ball to the wall within $30 \mathrm{~s}$ & $(n=25)$ & $(n=25)$ & $(n=25)$ & (C-F) $p<0.05$ \\
\hline - number of times, 'strong hand' & $35.4 \pm 0.892$ & $38.7 \pm 0.984$ & $42.2 \pm 0.915$ & $\begin{array}{l}\text { (C-D) } p<0.01 \\
\text { (F-D) } p<0.05\end{array}$ \\
\hline - number of times, 'weak hand' & $32.0 \pm 0.011$ & $35.2 \pm 0.856$ & $38.8 \pm 0.711$ & $\begin{array}{l}(\mathrm{C}-\mathrm{F}) p<0.05 \\
(\mathrm{C}-\mathrm{D}) p<0.01 \\
(\mathrm{~F}-\mathrm{D}) p<0.05\end{array}$ \\
\hline - number of times, two hands from the breast & $34.0 \pm 0.815$ & $37.9 \pm 0.372$ & $41.2 \pm 0.912$ & $\begin{array}{l}(\mathrm{C}-\mathrm{F}) p<0.05 \\
(\mathrm{C}-\mathrm{D}) p<0.001 \\
(\mathrm{~F}-\mathrm{D}) p<0.01\end{array}$ \\
\hline Foul shots from the distance of $30 \mathrm{~m}$ & $(n=15)$ & $(n=20)$ & & $(\mathrm{C}-\mathrm{F}) p<0.05$ \\
\hline - number of hits & $24.0 \pm 1.43$ & $25.15 \pm 0.875$ & $26.5 \pm 0.689$ & $\begin{array}{l}\text { (C-D) } p<0.01 \\
\text { (F-D) } p<0.05\end{array}$ \\
\hline Ball shooting in a jump from $40 \mathrm{~m}$ & $(n=23)$ & $(n=20)$ & $(n=28)$ & $(\mathrm{C}-\mathrm{F}) p<0.05$ \\
\hline - number of hits & $25.95 \pm 1.45$ & $27.04 \pm 1.62$ & $29.96 \pm 1.35$ & $\begin{array}{l}\text { (C-D) } p<0.01 \\
\text { (F-D) } p<0.99\end{array}$ \\
\hline - percentage of hits & $64.9 \pm 3.63$ & $67.6 \pm 4.06$ & $74.0 \pm 3.4$ & $\begin{array}{r}(\mathrm{C}-\mathrm{F}) p<0.05 \\
(\mathrm{C}-\mathrm{D}) p<0.01 \\
(\mathrm{~F}-\mathrm{D}) p<0.05\end{array}$ \\
\hline - work time $(\mathrm{min} / \mathrm{s})$ & $4.13 \pm 0.187$ & $4.25 \pm 1.108$ & $4.11 \pm 0.138$ & $\begin{array}{l}(\mathrm{C}-\mathrm{F}) p<0.05 \\
(\mathrm{C}-\mathrm{D}) p<0.05 \\
(\mathrm{~F}-\mathrm{D}) p<0.05\end{array}$ \\
\hline - general work ability in ball shooting (s) & $0.162 \pm 0.006$ & $0.157 \pm 0.039$ & $0.164 \pm 0.007$ & $\begin{array}{r}(\mathrm{C}-\mathrm{F}) p<0.05 \\
(\mathrm{C}-\mathrm{D}) p<0.05 \\
(\mathrm{~F}-\mathrm{D}) p<0.05\end{array}$ \\
\hline $\begin{array}{l}\text { - throwing technique efficiency till fatigue } \\
\text { (number of hits for } 1 \mathrm{~s} \text { ) }\end{array}$ & $0.105 \pm 0.008$ & $0.107 \pm 0.006$ & $0.125 \pm 0.007$ & $\begin{array}{r}(\mathrm{C}-\mathrm{F}) p<0.05 \\
(\mathrm{C}-\mathrm{D}) p<0.001 \\
(\mathrm{~F}-\mathrm{D}) p<0.001\end{array}$ \\
\hline Complex test $2 \times 26$ & $(n=18)$ & $(n=19)$ & $(n=18)$ & $(\mathrm{C}-\mathrm{F}) p<0.05$ \\
\hline - speed $(\mathrm{m} / \mathrm{s})$ & $14.8 \pm 0.646$ & $14.6 \pm 0.438$ & $13.67 \pm 0.705$ & $\begin{array}{l}\text { (C-D) } p<0.05 \\
\text { (F-D) } p<0.05\end{array}$ \\
\hline
\end{tabular}

\section{Discussion}

A significant contribution to the problem of assessing the level of physical preparation may be the study of the functional capabilities of basketball players [13-15]. The change during the game significantly influences aerobic and anaerobic metabolism indicators $[6,10,16]$.

It is known $[5,11,17]$ that one of the most important indicators of physical work capacity, which char- acterizes the level of development of aerobic functions, is the maximum oxygen consumption. The values of the maximum $\mathrm{O}_{2}$ consumption are lower than the similar indicators in representatives of other types of sports $[1,18,19]$.

It should be noted that in cyclic sports athletes, the maximum oxygen consumption reaches $70 \mathrm{ml} / \mathrm{kg}$ and above [15]. Relatively small values are recorded in indicators that characterize the level of development of aerobic and anaerobic performance of sportsmen. 
The results of the study supplement the information on the control of aerobic and anaerobic functions of basketball players regulating the expediency of pedagogical influences to ensure the efficiency of the basketball players' competitive activities [13-15, 18]. This knowledge enhances the effectiveness of preparation of highly skilled basketball players during long-term training [20-22].

\section{Conclusions}

1. The study has revealed that in $20.2 \%$ of cases, there is no difference between physical preparation indicators or the difference is uncertain in players with different functions. In the technical preparation indicators, this percentage is 30.5 . This shows, on the one hand, a certain progress in the system of training of highly qualified basketball players, and, on the other, the necessity to increase the efficiency of the training system for tall players, especially those performing functions of centre players.

2. The determination of the maximum of aerobic and anaerobic performance indicates that, despite positive changes, the system of preparation applied in basketball does not ensure sufficient influence upon the energy functions that form the basis of both general and special endurance. This is evidenced by the data obtained among basketball players of various game functions.

Future research should focus on the competitive activities efficiency in basketball players.

\section{Disclosure statement}

No author has any financial interest or received any financial benefit from this research.

\section{Conflict of interest}

The authors state no conflict of interest.

\section{References}

1. Altberg OY. Study of the process of training and competitive loads intensification for basketball players of the highest ranks [in Russian] (dissertation). Tartu; 1971.

2. Ben Abdelkrim N, Castagna C, El Fazaa S, El Ati J. The effect of players' standard and tactical strategy on game demands in men's basketball. J Strength Cond Res. 2010;24(10):2652-2662; doi: 10.1519/ JSC.0b013e3181e2e0a3.

3. Poplavskyi LY. Basketball [in Ukrainian]. Kyiv: Olimpiiska Literaturea; 2004.

4. Kostikova LV. Research of special endurance of basketball players and improving the ways of its development [in Russian] (dissertation). Moscow; 1973.
5. McArdle WD, Katch FI, Katch VL. Exercise physiology: energy, nutrition, and human performance. Philadelphia, London: Lea and Febiger; 1991.

6. Sallet P, Perrier D, Ferret JM, Vitelli V, Baverel G. Physiological differences in professional basketball players as a function of playing position and level of play. J Sports Med Phys Fitness. 2005;45(3):291-294.

7. Köklü Y, Alemdaroğlu U, Koçak FÜ, Erol AE, Fındıkoğlu G. Comparison of chosen physical fitness characteristics of Turkish professional basketball players by division and playing position. J Hum Kinet. 2011;30: 99-106; doi: 10.2478/v10078-011-0077-y.

8. Okazaki VHA, Rodacki ALF. Basketball jump shot performed by adults and children. Hum Mov. 2018;19(1): 71-79; doi: 10.5114/hm.2018.73615.

9. Danilov VA. Experimental research of the special working capacity of basketball players [in Russian] (dissertation). Moscow; 1972.

10. Zatsiorskiy V. Fundamentals of sports metrology [in Russian]. Moscow: Physical Culture and Sport; 2006.

11. Korjahin VM. Training of the highly skilled basketball players. Textbook for the correct physical education [in Ukrainian]. Lviv: Krai; 1998.

12. Koryagin V, Blavt O. Technological conversion of a system for test control of the leaping ability. Eur J Phys Educ Sport. 2015;1(7):46-52; doi: 10.13187/ejpe.2015.7.46.

13. Taylor HL, Buskirk E, Henschel A. Maximal oxygen intake as an objective measure of cardio-respiratory performance. J Appl Physiol. 1955;8(1):73-80; doi: 10.1152/ jappl.1955.8.1.73.

14. McInnes SE, Carlson JS, Jones CJ, McKenna MJ. The physiological load imposed on basketball players during competition. J Sports Sci. 1995;13(5):387-397; doi: 10.1080/02640419508732254.

15. Crisafulli A, Melis F, Tocco F, Santoboni UM, Frongia F, Carta C, et al. Anaerobic threshold and the oxygen consumption-cardiac output relationship during exercise. Sport Sci Health. 2005;1(2):75-80; doi: 10.1007/ s11332-2005-004-0014-3.

16. Sampaio J. Effects of season period, team quality, and playing time on basketball players' game-related statistics. Eur J Sport Sci. 2010;10(2):141-149; doi: 10.1080/ 17461390903311935.

17. Solodkov AS, Sologub EB. Human physiology. The general. Sports. Age [in Russian]. Moscow: Olympia Press; 2005.

18. Rozenblat VV. To the physiology of fatigue and working capacity in the muscular work of man [in Russian] (dissertation). Sverdlovsk; 1963.

19. Ramos J, Rubio JA, Martínez F, Esteban P, Jiménez J. Physiological, podological and somatometric characteristics of professional basketball player [in Spanish]. Arch Med Deporte. 2010;27(136):84-94.

20. Hoare DG. Predicting success in junior elite basketball players - the contribution of anthropometric and physiological attributes. J Sci Med Sport. 2000;3(4):391405; doi: 10.1016/S1440-2440(00)80006-7. 


\section{HUMAN MOVEMENT}

V. Koryahin et al., The technical and physical preparation of basketball players

21. Ryss AA. Research of functional changes in athletes basketball players under the influence of specialized training [in Russian] (dissertation). Perm; 1971.

22. Koryagin V, Blavt O, Grebinca G. Optimization of the technical training system. J Phys Educ Sport. 2016; 16(Suppl. 2):1029-1030; doi: 10.7752/jpes.2016.s2163. 